\title{
Azonaphthalene dyes decolorization and detoxification by laccase from Trametes versicolor
}

\author{
Barbora Legerská, Daniela Chmelová ${ }^{\bowtie}$ and Miroslav Ondrejovič \\ Department of Biotechnology, Faculty of Natural Sciences, University of SS. Cyril and Methodius in Trnava, J. Herdu 2, \\ Trnava, SK-917 01, Slovak Republic
}

\section{Article info}

Article history:

Received: $14^{\text {th }}$ October 2018

Accepted: $21^{\text {st }}$ November 2018

\section{Keywords:}

Azo dye

Decolorization

Detoxification

Laccase

Trametes versicolor

\section{Abbreviations:}

ABTS, 2,2'-azino-bis-3-

ethylbenzothiazoline-6-sulfonic acid

HBT, 1-hydroxybenzotriazole

MW, molecular weight

\begin{abstract}
The aim of the present study was to investigate the dye decolorization ability of laccase from Trametes versicolor. Five azonaphthalene dyes (Acid Violet 7, Acid Red 1, Allura Red AC, Orange G and Sunset Yellow FCF) were used to evaluate dye decolorization. Laccase from T. versicolor is capable of decolorizing dyes, namely Acid Violet $7(53.7 \pm 2.3 \%$ ) and Orange G (46.0 $\pm 2.2 \%)$. The less effective ability of laccase was observed at the decolorization of other selected dyes $(6.9-18.6 \%)$. The presence of redox mediator (1-hydroxybenzotriazole) increased decolorization percentage for all tested dyes $(\geq 90.5 \%)$. Toxic effect of azo dyes and their degradation products after laccase treatment was observed on the growth of selected bacteria (Micrococcus luteus, Bacillus subtilis, Pseudomonas syringae and Escherichia coli), yeasts (Candida parapsilosis and Saccharomyces cerevisiae) and algae (Chlorella vulgaris and Microcystis aeruginosa). It was confirmed that degradation products showed lower inhibition effect compared to initial dyes. These findings suggest that laccase from $T$. versicolor are able to decolorize and detoxify selected azonaphthalene dyes.
\end{abstract}

(C) University of SS. Cyril and Methodius in Trnava

\section{Introduction}

Azo dyes represent a group of synthetic dyes used in industrial processes for their stability and colour intensity (Gomez et al. 2013; Rovina et al. 2016). This group belongs to a large class of synthetic dyes containing one or more azo bonds $(-\mathrm{N}=\mathrm{N}-)$. These bonds link various aromatic ring structures (benzene, naphthalene).

Azonaphthalene dyes have naphthalene ring with delocalized conjugated bonds of carbon atoms stabilise total structure of azo dye (Zhu et al. 2012). Moreover, functional groups present in their structure are responsible for various physical properties such as solubility, lipophilicity or absorption (Legerská et al. 2016; Da Costa et al. 2017). Approximately $2-50 \%$ of synthetic dyes used in industrial dyeing operations have been discharged into wastewater (Sarkar et al. 2017).

Moreover, many works confirmed that azo dyes are toxic or carcinogenic for various organisms including human (Yang et al. 2009; GholamiBorujeni et al. 2011; Axon et al. 2012; Nath et al. 2016). Therefore, the elimination azo dyes from water systems by appropriate methods is essential for prevention of the environment contamination. For azo dye removal, some chemical and physicochemical methods have been traditionally used. Their disadvantages include sludge formation (Zhu et al. 2012; Lau et al. 2014; Youssef et al. 2016), high operating costs and toxic degradation products (Liakou et al. 1997; Lopez et al. 2004; Linley et al. 2012). Biological elimination of synthetic azo dyes is environmentally friendly and relatively 
Table 1. Characteristics of azonaphthalene dyes used in this study.

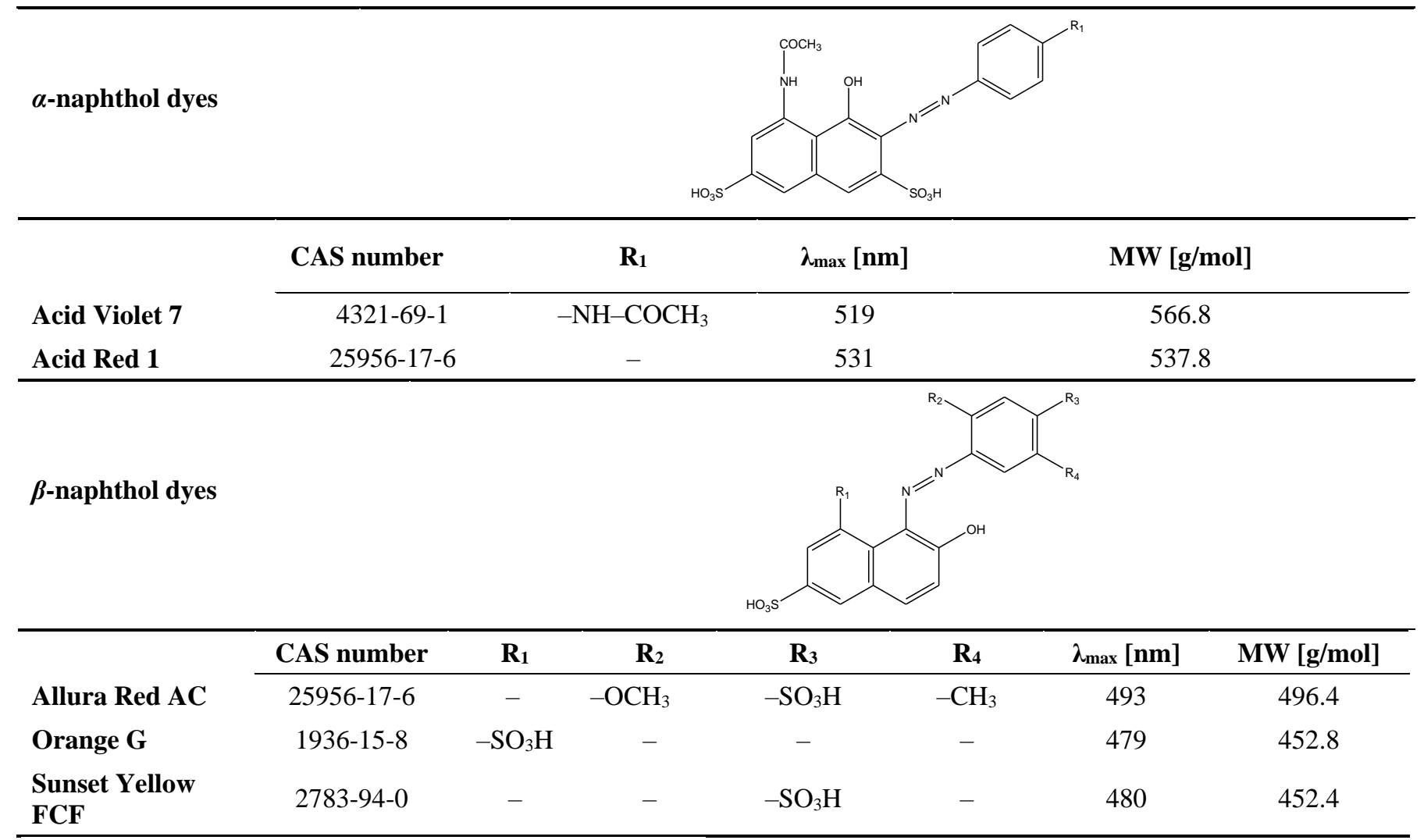

inexpensive. Moreover, the biological methods do not form any toxic degradation products (Sathe et al. 2015; Legerská et al. 2016, Chmelová and Ondrejovič 2016). Useful enzymes for this purpose seem to be azoreductases (EC 1.7.1.6), laccases (EC 1.10.3.2) and peroxidases (1.11.1.x) (Viswanath et al. 2014; Singh et al. 2015). In contrast to azoreductases and peroxidases, laccases catalyse dye decolorization in the presence of oxygen. Consequently, laccase dye decolorization offers more efficient degradation, low cost of enzymatic process and the production of non-toxic compounds comparing to other abovementioned enzymes (Casas et al. 2007; Chhabra et al. 2015).

While different organisms produce laccases including bacteria, fungi, plants and insect, the most perspective producers are white-rot fungi (Viswanath et al. 2014; Singh et al. 2015, Hazuchová et al. 2017) producing laccases with high redox potential (Baiocco et al. 2003; Pang et al. 2015). For example, laccases from Trametes versicolor have the redox potential approximately $785 \mathrm{mV}$, which allows oxidation of hardly- degradable organic compounds including various groups of dyes (Kurniawati and Nicell 2008; Legerská et al. 2018). Moreover, laccases produce non-toxic degradation products, which saprophytes can use as carbon source (Gavril and Hodson 2007; Selvam et al. 2012).

Therefore, the aim of this study was to evaluate potential of laccase from $T$. versicolor for decolorization and detoxification of synthetic dyes from the group of $\alpha$-naphthol (Acid Violet 7, Acid Red 1) and $\beta$-naphthol (Allura Red AC, Orange G, Sunset Yellow FCF) azo dyes.

\section{Experimental}

\section{Microorganisms}

Bacterial species (Micrococcus luteus CCM 1569, Bacillus subtilis CCM 2218, Pseudomonas syringae CCM 2114 and Escherichia coli CCM 7929) and yeast species (Candida parapsilosis CCM 8186, Saccharomyces cerevisiae CCM 8191) were purchased from Czech Collection of Microorganisms (Brno, Czech Republic). 
The algae Chlorella vulgaris H 1993 was purchased from Culture Collection of Algae (Prague, Czech Republic) and Microcystis aeruginosa PCC 7806 was obtained from Culture Collection of Cyanobacteria and Algae (Brno, Czech Republic).

\section{Dyes and chemicals}

Laccase from Trametes versicolor and selected naphthalene azo dyes (Table 1) were obtained from Sigma-Aldrich (Germany). Culture media were supplied by Biolife (Italy). All other chemicals were purchased from Mikrochem (Slovak Republic).

\section{Decolorization of azonaphthalene dyes by laccase}

Dye decolorization by laccase from $T$. versicolor was spectrophotometrically determined in the range of $300-700 \mathrm{~nm}$ (Spectrophotometer V-1600PC, VWR, Germany) during 5 days with or without the redox mediator 1-hydroxybenzotriazole (HBT). The reaction mixtures contained $50 \mathrm{mg} / \mathrm{L}$ of azonaphthalene dye in $0.1 \mathrm{~mol} / \mathrm{L}$ phosphate buffer ( $\mathrm{pH} 3.0$ ), and laccase from T.versicolor with enzyme activity of $1.0 \mathrm{U} / \mathrm{mL}$ mixed in ratio $3: 1(\mathrm{v} / \mathrm{v})$. The effect of $1.0 \mathrm{mmol} / \mathrm{L} \mathrm{HBT}$ was also tested. Control samples were run without the addition of laccase. The decolorization percentage was determined as follows:

$$
\text { decolorization }[\%]=\left[\left(A_{0}-A_{t}\right) / A_{0}\right] * 100,
$$

where $A_{0}$ is the initial absorbance and $A_{t}$ is the absorbance of enzymatic reaction at a certain time of laccase treatment.

\section{Toxicity test}

The effect of laccase treatment on toxicity of selected azonaphthalene dyes, namely Acid Violet 7 and Orange $\mathrm{G}$, were evaluated. The applied dye concentration range was $0.04-5.0 \mathrm{~g} / \mathrm{L}$. The growth inhibitions of selected microorganisms (bacteria, yeasts and algae) were assayed in the microtiter plates by dilution method during 48 and $72 \mathrm{~h}$ at $30{ }^{\circ} \mathrm{C}$ spectrophotometrically at $690 \mathrm{~nm}$. The results were expressed as minimum inhibitory concentration (MIC), which completely inhibits the growth of microorganism.

Production of chlorophylls and biomass was monitored for algae (C. vulgaris, $M$. aeruginosa) in media with selected azo dyes or their degradation products after laccase treatment. The cultivation was performed at laboratory temperature with $14: 10 \mathrm{~h}$ light and dark photoperiod. After 30 days of cultivation, the concentration of chlorophylls $a$ and $b$ in algal biomass were expressed according Sumanta et al. (2014) as follows:

$$
\begin{aligned}
& \text { chlorophyll } a=16.72 A 665 \mathrm{~nm}-9.16 A 652 \mathrm{~nm} \\
& \text { chlorophyll } b=34.09 A 654 \mathrm{~nm}-15.28 A 665 \mathrm{~nm}
\end{aligned}
$$

The results were expressed as the inhibition percentage toward the control without synthetic dye or degradation products of dye after laccase treatment. The inhibition of biomass formation was calculated as follows:

$$
\text { biomass inhibition }[\%]=\left[\left(B_{c}-B_{d}\right) / B_{c}\right] * 100 \text {, }
$$

where $B_{c}$ is biomass weight of control sample without azo dye and $B_{d}$ is biomass weight of sample with selected azo dye. The inhibition of chlorophyll production was calculated as follows:

$$
\text { chlorophyll inhibition }[\%]=\left[\left(C_{c}-C_{d}\right) / C_{c}\right] * 100 \text {, }
$$

$C_{c}$ is the concentration of selected chlorophyll $a$ or $b$ in control sample and $C_{d}$ is the concentration of selected chlorophyll $a$ or $b$ in sample with azo dye or degradation products after laccase treatment.

\section{HPLC analysis}

The degradation mixtures of selected azonaphthalene dyes (Acid Violet 7 and Orange G) were analysed with high performance liquid chromatography HPLC (Agilent Technologies 1200 Series, USA) on C18 column $(3.5 \mu \mathrm{L}, 3.0 \mathrm{~mm}$ x $100 \mathrm{~mm})$ using mobile phase A $(0.1 \%(v / v)$ aqueous solution of formic acid) and B $(0.1 \%(\mathrm{v} / \mathrm{v})$ methanolic solution of formic acid). The gradient program was set as follows: $0-2 \mathrm{~min}=0-20.0 \%$ $\mathrm{B}, 2-15 \mathrm{~min}=20.0-95.0 \% \mathrm{~B}, 15-20 \mathrm{~min}=$ $95.0 \%$ B. The flow rate was $0.7 \mathrm{~mL} / \mathrm{min}$ and the absorbance of eluted compounds was measured at $254 \mathrm{~nm}$. 


\section{Results and Discussion}

\section{Decolorization of selected azonaphthalene dyes}

Laccases are often studied for their potential of dye decolorization. Five azonaphthalene dyes, Acid Violet 7, Acid Red 1, Allura Red AC, Orange G and Sunset Yellow FCF, were used to evaluate the
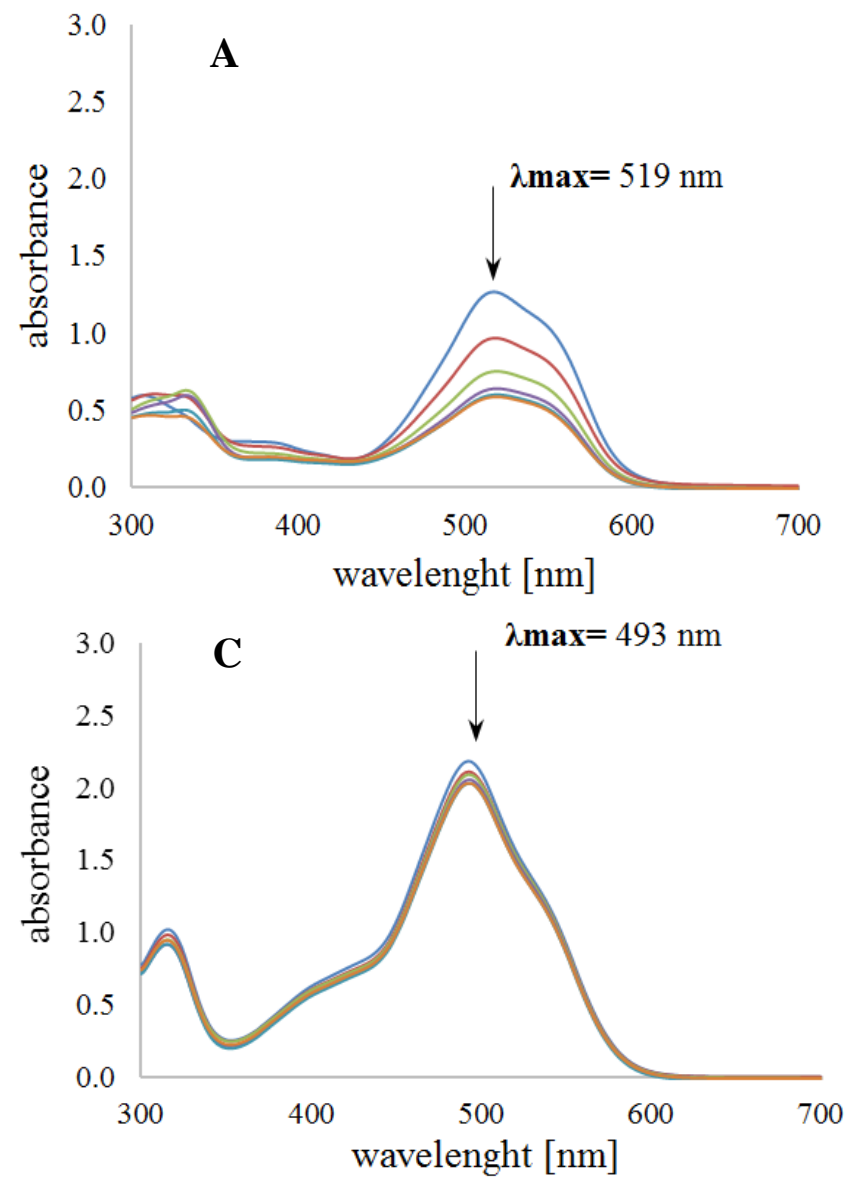

dye decolorization efficiency of laccase from T. versicolor (Fig. 1). Laccases from T. versicolor were able to decolorize the $\alpha$-naphtol dye Acid Violet 7 (53.7 $\pm 2.3 \%$ ) (Fig. 1-A). The $\alpha$-naphtol dye Acid Red 1 was decolorized by laccase less effectively $\quad(16.7 \pm 0.1 \%) \quad$ (Fig. 1-B). Dye degradation by laccase is influenced by chemical structure of dye itself, differences in electron
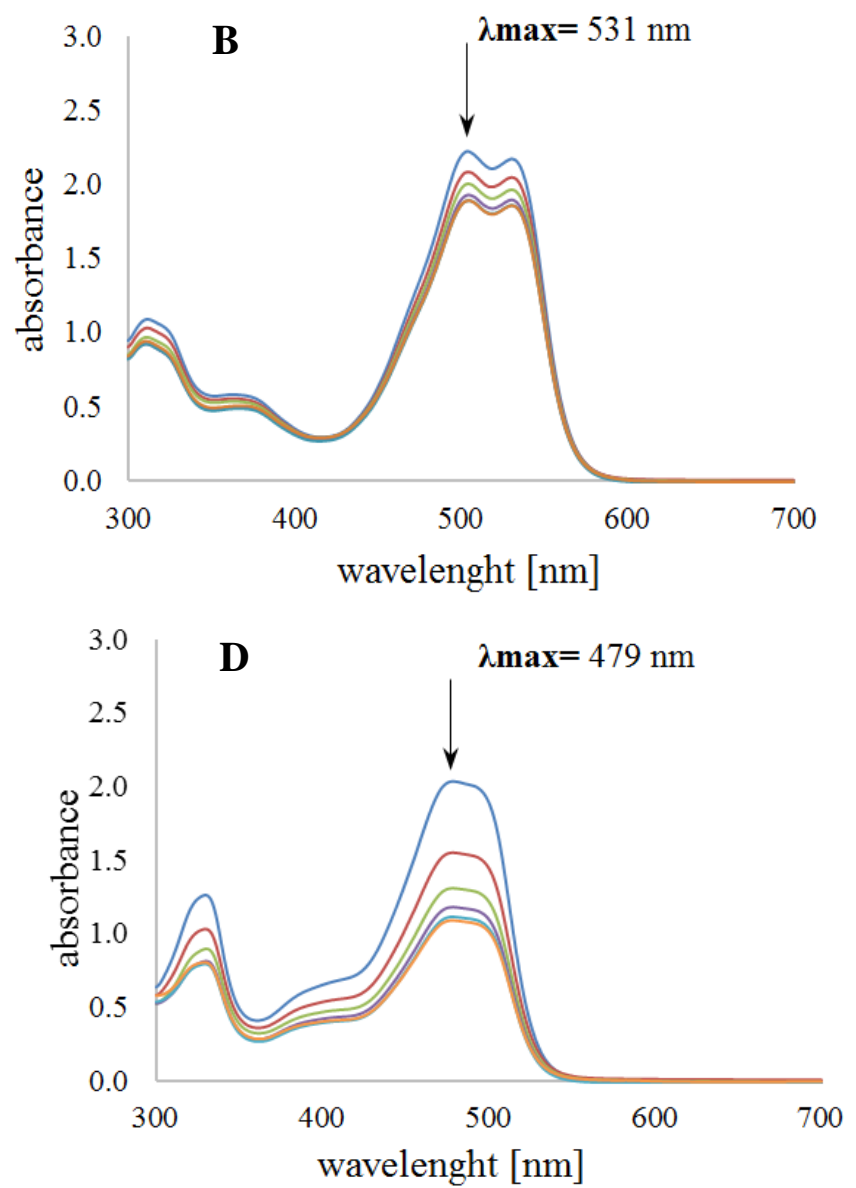

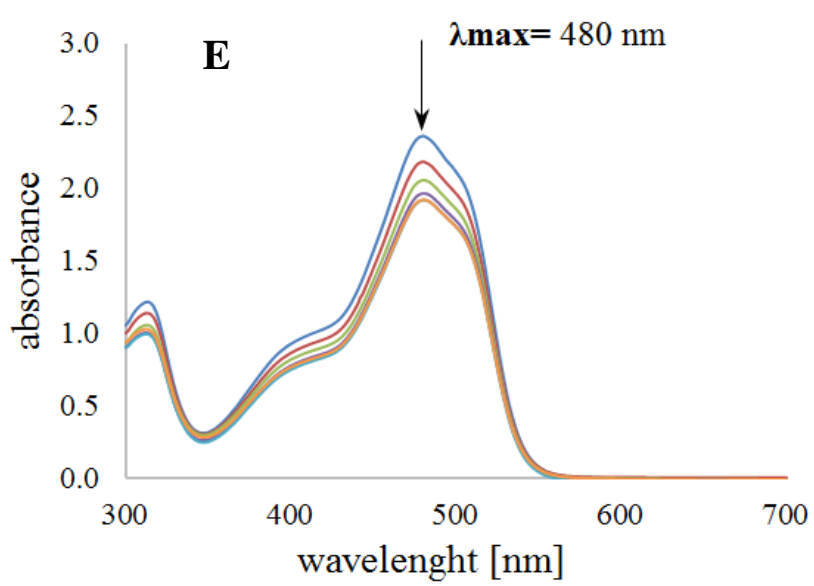

Fig. 1. UV-VIS spectrum of the reaction mixture of the naphthalene dye A - Acid Violet 7, B - Acid Red 1, C - Allura Red AC, D - Orange G and $\mathbf{E}$ - Sunset Yellow FCF decolorized with laccase from Trametes versicolor during 5 days at $\mathrm{pH} 3.0$ and $22{ }^{\circ} \mathrm{C}(-0$. day, -1 . day, -2 . day, -3 . day, -4 . day, -5 . day $)$. 
Table 2. The effect of 1-hydroxybenzotriazole (HBT) on laccase catalysed decolorization of selected azo dyes.

\begin{tabular}{lcc}
\hline \multirow{2}{*}{ Azo Dyes } & \multicolumn{2}{c}{ Decolorization [\%] } \\
\cline { 2 - 3 } & $\begin{array}{c}\text { Laccase } \\
\text { without HBT }\end{array}$ & $\begin{array}{c}\text { Laccase-HBT } \\
\text { mediated System }\end{array}$ \\
\hline $\boldsymbol{\alpha}$-naphtol dyes & & \\
Acid Violet 7 & $53.7 \pm 2.3$ & $97.1 \pm 0.3$ \\
Acid Red 1 & $16.7 \pm 0.1$ & $95.0 \pm 0.5$ \\
\hline $\boldsymbol{\beta}$-naphtol dyes & & \\
Allura Red AC & $6.9 \pm 0.2$ & $95.8 \pm 0.1$ \\
Orange G & $46.0 \pm 2.2$ & $96.8 \pm 0.7$ \\
Sunset Yellow FCF & $18.6 \pm 1.2$ & $95.0 \pm 1.5$ \\
\hline
\end{tabular}

distribution, number of dissociating groups and steric barriers (Hsueh et al. 2009). The poorest was decolorization of Acid Red 1 probably because of the presence of $-\mathrm{COCH}_{3}$ group bonded to the naphtol ring of Acid Red 1. Similarly, other authors described partial decolorization of these dyes. Zhang et al. (2006) tested the degradation ability of laccase from Panus rudis for Acid Violet 7 and reported decolorization of $26.0 \%$. This substituent belongs to electron-withdrawing group making a ring less susceptible to enzymatic oxidation (Suzuki et al. 2001). In contrast to our results, Zhou et al. (2017) observed higher decolorization of Acid Red 1 (69.7\%) after enzymatic reaction with laccase from Bacillus pumilus W3. The efficiency of the decolorization process, therefore, is obviously influenced by the choice of producer. Different producers produce laccase with various redox potential resulting in variable decolorization efficiency (Baiocco et al. 2003; Pang et al. 2015).
Of the $\beta$-naphtol dyes, the highest decolorization by $T$. versicolor laccases was showed for Orange $\mathrm{G}$ (46.0 $\pm 2.2 \%)$ (Fig. 1-D). The other $\beta$-naphtol dyes, Sunset Yellow FCF and Allura Red AC, were decolorized less effectively $(18.6 \pm 1.2 \%$ and $6.9 \pm 0.2 \%$, respectively) (Fig. 1-C,E). The efficient decolorization of Orange $\mathrm{G}$ was probably caused by the presence of two sulfo groups linked to the naphtol ring (Table 1), which allows simple degradation of dye chromophore. Sunset Yellow FCF has the similar structure as Orange G, however, the presence of single $-\mathrm{SO}_{3} \mathrm{H}$ group on the benzene ring significantly reduces structure stabilization. The lowest decolorization was observed in the mixture of Allura Red AC and laccase from $T$. versicolor $(6.9 \pm 0.2 \%)$. The presence of methyl- and methoxy groups on the benzene ring restricted decolorization. These groups stabilize the dyes and prevent their effective oxidation by laccase (Chivukula and Renganathan 1995; Hsueh et al. 2009).

The dye decolorization by laccases can be enhanced using low molecular compounds, also called redox mediators. In our work, we tested the effect of 1-hydroxybenzotriazole (HBT) as synthetic redox mediator on laccase catalysed decolorization of selected azo dyes. The results are shown in Table 2.

The presence of HBT increased the degree of decolorization of all tested dyes (Table 2), while the decolorization percentages varied in the range of $95.0-97.1 \%$. Forootanfar et al. (2016)

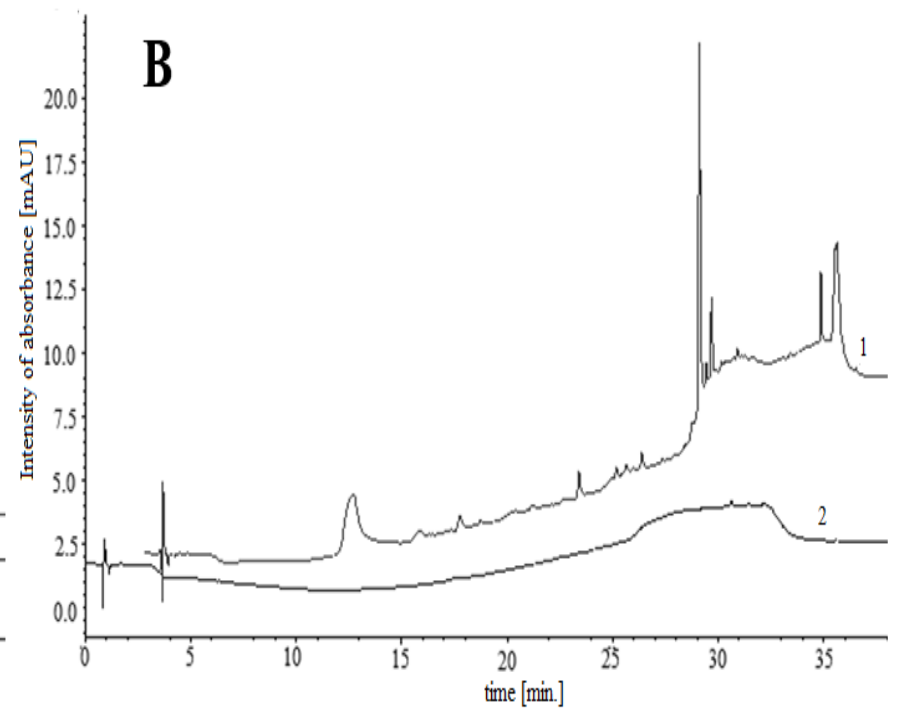

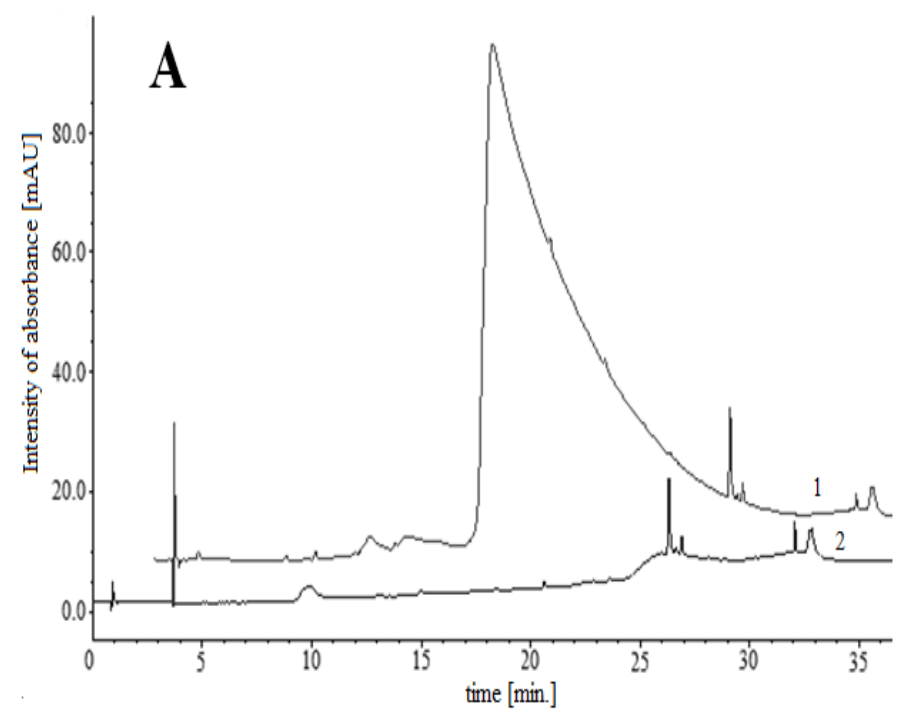

Fig. 2. HPLC elution profile of azonaphthalene dyes (1) (A - Acid Violet 7, B - Orange G) and their degradation products (2) obtained after treatment with laccase from $T$. versicolor. 
found that the presence of redox mediator (HBT) with laccase from Paraconiothyrium variabile increased the decolorization of azo dye and decreased the needed time for degradation. Wong and $\mathrm{Yu}$ (1999) reported that laccase from T. versicolor decolorized Acid Violet 7 more effectively in the presence of redox mediator (ABTS) in the reaction mixture. Furthermore, Zeng et al. (2011) reported decolorization of Acid Red 1 only in the laccaseHBT mediated system. It seems that the selection of appropriate redox mediator can increase the efficiency of decolorization process catalysed by laccases.

\section{Degradation products analysis}

Several authors (Yang et al. 2009; GholamiBorujeni et al. 2011; Axon et al. 2012; Nath et al. 2016) describe the potential toxic effect of dye degradation products. Therefore, two best decolorized dyes were assessed for the effect of laccase treatment. Degradation products of synthetic dyes after enzymatic degradation can be mainly analysed by HPLC or GC-MS (Franciscon et al. 2012; Christiane et al. 2013; Yuan et al. 2016). In our work, HPLC was used as a tool for analysis of dye decolorization and detection of emerging products. The results are shown in Fig. 2.

HPLC analysis of Acid Violet 7 (Fig. 2-A) displayed a single peak at retention time 15.457 min. After laccase treatment, the loss of the main peak indicates decolorization of initial dye. Similarly, HPLC analysis of Orange G (Fig. 2-B) displayed peaks at $25.310 \mathrm{~min}, 26.888 \mathrm{~min}$, $32.070 \mathrm{~min}$ and $32.839 \mathrm{~min}$. In reaction mixture with degradation products after laccase catalysed reaction, non-detectable peaks were observed. Although, new peaks were not detected, disappearance of the main peaks in Acid Violet 7 $(15.457 \mathrm{~min})$ and Orange $\mathrm{G}(25.310 \mathrm{~min})$ profiles point to the effectivity of laccase from $T$. versicolor to decolorization azonaphthalene dyes without production of other detectable compounds.

\section{Toxicity tests}

Azo dyes belong to toxic compounds with potential toxic effect on prokaryotic and/or eukaryotic organisms (Przystas et al. 2012; Lade et al. 2015). The loss of dye colour after laccase treatment indicates the breakdown of parent compound. However, degradation products can also be potentially toxic. Therefore, toxicity tests of selected azo dyes, namely Acid Violet 7 and Orange $\mathrm{G}$, with the highest decolorization after laccase treatment were performed (Table 3).

The toxicity of Acid Violet 7 on the growth of all bacteria (M. luteus, B. subtilis, P. syringae, E. coli) and the yeast $C$. parapsilosis was observed at dye concentration of $5.0 \mathrm{~g} / \mathrm{L}$, except of $S$. cerevisiae (>5.0 g/L). Similarly, Mansour et al. (2010) recorded toxicity of Acid Violet 7; this azo Dye induced chromosomal aberrations, lipid

Table 3. The minimum inhibitory concentrations of azonaphthalene dyes to the growth of prokaryotic and eukaryotic organisms before and after laccase treatment.

\begin{tabular}{|c|c|c|c|c|}
\hline & \multicolumn{4}{|c|}{ Minimum inhibitory concentration $[\mathrm{g} / \mathrm{L}]$} \\
\hline & \multicolumn{2}{|c|}{ Acid Violet 7} & \multicolumn{2}{|c|}{ Orange G } \\
\hline & Synthetic Dye & $\begin{array}{c}\text { Degradation } \\
\text { Products } \\
\end{array}$ & Synthetic Dye & Degradation Products \\
\hline \multicolumn{5}{|l|}{ Bacteria } \\
\hline M. luteus & 5.0 & - & 5.0 & - \\
\hline B. subtilis & 5.0 & - & 5.0 & - \\
\hline E. coli & 5.0 & - & - & - \\
\hline P. syringae & 5.0 & - & - & - \\
\hline \multicolumn{5}{|l|}{ Yeasts } \\
\hline C. parapsilosis & 5.0 & - & - & - \\
\hline S. cerevisiae & - & - & - & - \\
\hline
\end{tabular}

- without inhibitory effect on bacterial and yeast growth in concentration range of $0.04-5.0 \mathrm{~g} / \mathrm{L}$. 
Table 4. The inhibitory effects of Acid Violet 7 and Orange $G$ and their degradation products after laccase treatment on the biomass and chlorophylls production of selected algae.

\begin{tabular}{|c|c|c|c|c|}
\hline & & & \multicolumn{2}{|c|}{ Inhibitory rate [\%] } \\
\hline & & & C. vulgaris & M. aeruginosa \\
\hline \multirow{6}{*}{ Acid Violet 7} & \multirow{3}{*}{ Synthetic Dye } & biomass & $37.8 \pm 3.2$ & - \\
\hline & & chlorophyll $a$ & $14.5 \pm 2.8$ & $56.7 \pm 4.6$ \\
\hline & & chlorophyll $b$ & $12.9 \pm 1.2$ & $56.1 \pm 3.7$ \\
\hline & \multirow{3}{*}{ Degradation Products } & biomass & $21.9 \pm 1.8$ & - \\
\hline & & chlorophyll $a$ & $6.9 \pm 0.4$ & - \\
\hline & & chlorophyll $b$ & $8.8 \pm 2.9$ & - \\
\hline \multirow{6}{*}{ Orange $\mathbf{G}$} & \multirow{3}{*}{ Synthetic Dye } & biomass & $30.3 \pm 4.9$ & - \\
\hline & & chlorophyll $a$ & $14.8 \pm 2.1$ & $72.1 \pm 3.1$ \\
\hline & & chlorophyll $b$ & $10.7 \pm 2.1$ & $71.2 \pm 4.7$ \\
\hline & \multirow{3}{*}{ Degradation Products } & biomass & $10.6 \pm 3.6$ & - \\
\hline & & chlorophyll $a$ & - & - \\
\hline & & chlorophyll $b$ & - & - \\
\hline
\end{tabular}

- without inhibitory effect to the growth of algae species.

peroxidation and cholinesterase inhibition in mouse bone marrow. On the other hand, in our study, Orange $\mathrm{G}$ inhibited only the growth of $M$. luteus and B. subtilis (Table 3), its growth inhibitory effect was not observed on other tested microorganisms. This lack of toxicity of Orange $G$ is consistent with the results of Mariappan et al. (2003) for bacterial species Pseudomonas sp. SAC03, Bacillus sp. SAC01 and Escherichia sp. SAC01, and also Alcántara et al. (2017) for yeast species. Previous studies have indicated that the toxicity of azo dyes strongly depends on chemical structure, functional groups and the number of azo bonds (Costa et al. 2012; Legerská et al. 2016; Da Costa et al. 2017). This was also confirmed in this study showing the relatively higher toxicity of $\alpha$-naphtol dye Acid Violet 7 comparing to $\beta$-naphtol dye Orange G. Even more importantly, laccase treatment resulted in degradation products with no toxicity on tested microorganisms (Table 3).

The presence of synthetic dyes in environment also affects the growth of photosensitive microorganisms. Therefore, we tested the impact of laccase-degraded dyes on growth of selected algae, namely $C$. vulgaris and $M$. aeruginosa. Contents of chlorophyll $a$ and $b$ were measured. The results are shown in Table 4.

The presence of Acid Violet 7 and Orange $G$ in medium inhibited the growth of $C$. vulgaris as well as the production of chlorophyll $a$ and $b$ of both algae species (Table 4). In culture media with degradation products after laccase treatment, the reduction and even disappearance of toxicity effect were observed. Influence of azo dye on $C$. vulgaris growth was also studied in the work of Hernández-Zamora et al. (2014) who revealed significant decrease of biomass and chlorophyll production. El-Sheekh et al. (2017) confirmed the negative influence of azo dye Disperse Red BS on growth of $M$. aeruginosa.

\section{Conclusions}

The results from this study showed the ability of laccase from Trametes versicolor to decolorize synthetic dyes from model systems. As expected, decolorization was observed in all dye reaction mixture. Laccase from $T$. versicolor showed the highest decolorization with Acid Violet 7, the $\alpha$-naphthol azo dye, and with Orange G, the $\beta$-naphthol azo dye while the addition of HBT increased the effectivity of dye degradation. HPLC analysis of decolorized solutions confirmed absence of distinguishable degradation products and complete loss of the main peak representing azo dye. The dye toxicity toward bacteria, yeasts and algae after laccase catalysed reaction was decreased. Our results show that laccases from the white rot fungus $T$. versicolor are suitable for decolorization and detoxification of azonaphthalene dyes, while generate environmentally friendly degradation products. 


\section{Acknowledgement}

This work was supported by the Slovak Research and Development Agency under contract number APVV-160088 .

\section{References}

Alcántara TAP, Oliveira JM, Evangelista-Barreto NS, Marbac PAS, Cazetta ML (2017) Aerobic decolorization o azo dye Orange $G$ by a new yeast isolate Candida cylindracea SJL6. Biosci. J. 33: 1340-1350.

Axon A, May FE, Gaughan LE, Williams FM, Blain PG, Wright MC (2012) Tartrazine and sunset yellow are xenoestrogens in a new screening assay to identify modulators of human oestrogen receptor transcriptional activity. Toxicology. 298: 40-51.

Baiocco P, Barreca AM, Fabbrini M, Galli C, Gentili P (2003) Promoting laccase activity towards non-phenolic substrates: a mechanistic investigation with some laccase-mediator systems. Org. Biomol. Chem. 1: 191197.

Casas N, Blanquez P, Gabarrell X, Vincent T, Caminal G, Sarra M (2007) Degradation of Orange $G$ by laccase: fungal versus enzymatic process. Environ. Technol. 28: 1103-1110.

Chhabra M, Mishra S, Sreekrishnan TR (2015) Immobilized laccase mediated dye decolorization and transformation pathway of azo dye acid red 27, J. Environ. Health Sci. Eng. 13: 1-9.

Chivukula M, Renganathan V (1995) Phenolic azo dye oxidation by laccase from Pyricularia oryzae. Appl. Environ. Microbiol. 34: 4374-4377.

Chmelová D, Ondrejovič M (2016) Purification and characterization of extracellular laccase produced by Ceriporiopsis subvermispora and decolorization of triphenylmethane dyes. J. Basic. Microbiol. 56: 11731182.

Christiane A, Steeve M, Jean-Bosco ST, Kor NM, Brama I, Eric G, Gerardin P (2013) Biodegradation of reactive blue 4 and orange $\mathrm{G}$ by Pycnoporus sanguineus strain isolated in Gabon. J. Bioremed. Biodeg. 4: 1-7.

Costa MC, Mota FSB, Dos Santos AB, Mendonca GLF, Ferreira do Nascimento R (2012) Effect of dye structure and redox mediators on anaerobic azo and anthraquinone dye reduction. Quim. Nove. 35: 1-9.

Da Costa SIC, Da Silva DR, Do Nascimento JHO, GarciaSegura S, Martínez-Huitle CA (2017) Functional group influences on the reactive azo dye decolorization performance by electrochemical oxidation and electroFenton technologies. Environ. Sci. Pollut. Res. Int. 24: 24167-24176.

El-Sheekh MM, Abou-El-Souod GW, El Asrag HA (2017) Biodegradation of some dyes by the cyanobacteria species Pseudoanabeana sp. and Microcystis aeruginosa Kützing. Egypt J. Exp. Biol. Bot. 13: 233-243.

Forootanfar H, Rezaei S, Zeinvand-Lorestani H, Tahmasbi H, Mogharabi M, Ameri A, Faramarzi, MA (2016) Studies on the laccase-mediated decolorization, kinetic, and microtoxicity of some synthetic azo dyes. J. Environ. Health Sci. Eng. 14: 1-9.

Franciscon E, Grossman MJ, Paschoal JAR, Reyes Reyes FG, Durrant LR (2012) Decolorization and biodegradation of reactive sulfonated azo dyes by a newly isolated Brevibacterium sp. strain VN-15. Sprinderpuls 1: 1-10.

Gavril M, Hodson PV (2007) Investigation of the toxicity of the products of decolorization of Amaranth by Trametes versicolor. J. Environ. Qual. 36: 1591-1598.

Gholami-Borujeni F, Mahvi AH, Nasseri S, Faramarzi MA, Nabizadeh R, Alimohammadi M (2011) Enzymatic treatment and detoxification of acid orange 7 from textile wastewater. Appl. Biochem. Biotechnol. 165: 1274-1284.

Gomez KMS, Aquiar de Oliveira MVG, Carvalho FRS, Menezes CC, Peron AP (2013) Citotoxicity of food dyes sunset yellow (E-110), bordeaux red (E-123), and tatrazine yellow (E-102) on Allium cepa L. root meristematic cells. J. Food Sci. Technol. 33: 218-223.

Hazuchová M, Chmelová D, Ondrejovič M (2017) The optimization of propagation medium for the increase of laccase production by the white-rot fungus Pleurotus ostreatus. Nova Biotechnol. Chim. 16: 113123.

Hernandéz-Zamora M, Perales-Vela HV, Flores-Ortíz CM, Cañizares-Villanueva RO (2014) Physiological and biochemical responses of Chlorella vulgaris to Congo red. Ecotoxicol. Environ. Saf. 108: 72-77.

Hsueh CC, Chen BY, Yen CY (2009) Understanding effects of chemical structure on azo dye decolorization characteristic by Aeromonas hydrophila. J. Hazard. Mater. 167: 995-1001.

Kurniawati S, Nicell JA (2008) Characterization of Trametes versicolor laccase for the transformation of aqueous phenol. Bioresour. Technol. 99: 7825-7834.

Lade H, Kadam A, Paul D, Govindwar S (2015) Biodegradation and detoxification of textile azo dyes by bacterial consortium under sequential microaerophilic/aerobic processes. Excli. J. 14: 158-174.

Lau YY, Wong YS, Teng TT, Morad N, Rafatullah M, Ong SA (2014) Coagulation- flocculation of azo dye Acid Orange 7 with green refined laterite soil. Chem. Eng. J. 246: 383-390.

Legerská B, Chmelová D, Ondrejovič M (2016) Degradation of synthetic dyes by laccase - a mini review. Nova Biotechnol. Chim. 15: 90-106.

Legerská B, Chmelová D, Ondrejovič M (2018) Decolourization and detoxification of monoazo dyes by laccase from the white-rot fungus Trametes versicolor. J. Biotechnol. 285: 84-90.

Liakou S, Pavlou S, Lyberatos G (1997) Ozonation of azo dyes. Water Sci. Technol. 35: 279-286.

Linley E, Denyer SP, McDonnell G, Simons C, Maillard JY (2012) Use of hydrogen peroxide as a biocide: new consideration of its mechanisms of biocidal action. J. Antimicrob. Chemother. 67: 1589-1596.

Lopez A, Benbelkacem H, Pic JS, Debellefontaine H (2004) Oxidation pathways for ozonation of azo dyes 
in a semi-batch reactor: a kinetic parameters approach. Environ. Technol. 25: 311-321.

Mansour BH, Ayed-Ajmi Y, Mosrati R, Corroler D, Ghedira K, Barillier D, Chekir-Ghedira L (2010) Acid Violet 7 and its biodegradation products induce chromosome aberrations, lipid peroxidation, and cholinesterase inhibition in mouse bone marrow. Environ. Sci. Pollut. Res. Int. 17: 1371-1378.

Mariappan C, Gayathri TVD, Yamuna RL, Palaniappan R, Selvamohan T (2003) Orange-G tolerance, utilization and degradation potentials of native bacterial isolates. Biosci. Biotechnol. Res. Asia 1: 87-91.

Nath PP, Sarkar K, Mondal M, Paul G (2016) Metanil yellow impairs the estrous cycle physiology and ovarian folliculogenesis in female rats. Environ. Toxicol. 31: 2057-2067.

Pang R, Li M, Zhang CH (2015) Degradation of phenolic compounds by laccase immobilized on carbon nanomaterials: Diffusional limitation investigation. Talanta 131: 38-45.

Przystas W, Zablocka-Godlewska E, Grabinska-Sota E (2012) Biological removal of azo and triphenylmethane dyes and toxicity of process by-products. Water Air Soil Pollut. 223: 1581-1592.

Rovina K, Shafiguyyaman S, Shaarani SM (2016) Extraction, analytical and advanced methods for detection of Allura Red AC (E129) in food and beverages products. Front. Microbiol. 7: 1-13.

Sarkar S, Banerjee A, Halder U, Biswas R, Bandopadhyay R (2017) Degradation of synthetic azo dyes of textile industry: a sustainable approach using microbial enzymes. Water Conserv. Sci. Eng. 2: 121-131.

Sathe S, Durand PM (2015) A low cost, non-toxic biological method for harvesting algal biomass. Algal Res. 11: 169-172.

Selvam K, Priya SM, Yamuna M (2012) Decolorization of azo dyes and dye industry effluents by lignin degrading fungus Trametes versicolor. Int. J. Pharm. Biol. Arch. 3: 666-672.

Singh RL, Singh PK, Singh RP (2015) Enzymatic decolorization and degradation of azo dyes a review. Int. Biodeterior. Biodegradation 104: 21-31.
Sumanta N, Haque CHI, Nishika J, Suprakash R (2014) Spectrophotometric analysi of chlorophylls and carotenoids from commonly growth fern species by using various extracting solvents. Res. J. Chem. Sci. 4: 63-69.

Suzuki T, Timofei S, Kurunczi L, Dietze U, Schuurmann G (2001) Correlation of aerobic biodegradability of sulfonated azo dyes with the chemical structure. Chemosphere 45: 1-9.

Viswanath B, Rajesh B, Janardhan A, Praveen Kumar A, Narasimha G (2014) Fungal laccases and their applications in bioremediation. Enzyme Res. 2014: 1-21.

Wong Y, Yu J (1999) Laccase-catalyzed decolorization of synthetic dyes. Water Res. 33: 3512-3520.

Yang Q, Li C, Li H, Li Y, Yu N (2009) Degradation of synthetic reactive azo dyes and treatment of textile wastewater by a fungi consortium reactor. Biochem. Eng. J. 43: 225-230.

Youssef NA, Shaban SA, Ibrahim FA, Mahmoud AS (2016) Degradation of methyl orange using Fenton catalytic reaction. Egypt. J. Petrol. 25: 317-321.

Yuan X, Tian G, Zhao Y, Zhao L, Wang H, Ng TB (2016) Degradation of dyes using crude extract and a thermostable and $\mathrm{pH}$-stable laccase isolated from Pleurotus nebrodensis. Biosci. Rep. 36: 1-10.

Zeng X, Cai Y, Liao X, Zeng X, Li W, Zhang D (2011) Decolorization of synthetic dyes by crude laccase from a newly isolated Trametes trogii strain cultivated on solid agro-industrial residue. J. Hazard. Mater. 187: 517525.

Zhang M, Wu F, Wei Z, Xiao Z, Gong W (2006) Characterization and decolorization ability of a laccase from Panus rudis. Enzyme Microb. Technol. 38: 92-97.

Zhou W, Gua ZB, Chen Y, Zhang F, Cai YJ, Xu CW, Chen XS, Liao XR (2017) Production of spore laccase from Bacillus pumilus W3 and its application in dye decolorization after immobilization. Water Sci. Technol. 76: 147-154.

Zhu N, Gu L, Yuan H, Lou Z, Wang L, Zhang X (2012) Degradation pathway of the naphthalene azo dye intermediate 1-diazo-2-naphthol-4-sulfonic acid using Fenton's reagent. Water Res. 46: 3859-3867. 